\title{
Evaluation of Tomato (Solanum lycopersicum L.) Hybrids during Rainy Season in Coastal Plain of Odisha, India
}

\author{
Rojalin Pradhan $^{1 *}$, Alok Nandi ${ }^{2}$, G.S. Sahu ${ }^{1}$ and P. Tripathy ${ }^{1}$ \\ ${ }^{1}$ Department of Vegetable Science, College of Agriculture, Orissa University of Agriculture \\ and Technology, Bhubaneswar-751003, Odisha, India \\ ${ }^{2}$ Department of Horticulture, Institute of Agricultural Sciences, Siksha-O-Anusandhan \\ (Deemed to be University), Bhubaneswar-751029, Odisha, India
}

*Corresponding author

\section{A B S T R A C T}

Tomato grown during the main season (winter) causes a glut of produce in the market and its sale price is also very low. But the crop grown in rainy season has a better demand and is much remunerative for the farmer. Therefore, the present experiment was undertaken to develop and identify tomato hybrids well adapted to the rainy season. The experiment was

\section{Keywords}

Tomato, Offseason, Evaluation, Rainy season, Hybrid

Article Info

Accepted:

17 June 2019

Available Online:

10 July 2019

conducted at the All India Co-ordinated Research Project on Vegetable Crops, Orissa University of Agriculture and Technology, Bhubaneswar. Forty five $\mathrm{F}_{1}$ hybrids were developed by crossing 10 divergent parental lines in half diallel fashion during 2016-17 (winter). The $45 \mathrm{~F}_{1}$ hybrids along with the 10 parents were evaluated in Randomised Block Design with three replications during the rainy season of 2017. Analysis of variance revealed significant differences among the hybrids for all the characters. The parent BT 317 proved to be the best with respect to characters like fruit yield per plant, average fruit weight, plant height, fruits per plant, fruit girth, fruit pericarp thickness, no. of clusters per plant and no. of locules per fruit. The hybrids BT 217 x BT 215-3-3-1 and TOBW-3 x BT 215-3-3-1 proved to be best with regard to fruit yield/plant (943.64 $\mathrm{g}$ and $651.24 \mathrm{~g}$ respectively), average fruit weight $(37.00 \mathrm{~g}$ and $35.20 \mathrm{~g}$ in order $)$, fruit length $(5.96 \mathrm{~cm}$ and $6.10 \mathrm{~cm})$, fruit girth $(5.86 \mathrm{~cm}$ and $5.70 \mathrm{~cm})$, fruits per plant $(27.18)$. BT $106 \mathrm{x}$ BT317 was promising for earliness i.e. days to first flowering (64.00 days). The hybrid BT 305-2-4-2 x BT 215-3-3-1 was the best for fruit pericarp thickness $(0.64 \mathrm{~cm})$. In respect of plant height, the hybrid BT317x BT 429-1-1was found to be promising $(110.40 \mathrm{~cm})$. Fruit length of BT 215-3-3-1 was the maximum.

\section{Introduction}

Tomato (Solanum lycopersicum L.) is one of the most popular and widely grown vegetables in the world. It belongs to the family Solanaceae. It originated in a wild form in the Peru-Ecuador Bolivia region of the Andes in
South America. It is a major source of vitamins and minerals particularly vitamin $\mathrm{C}$ (31.0 mg), vitamin A (321 IU), protein (1.98 $\mathrm{g})$, moisture $(93.1 \mathrm{~g})$, minerals $(0.6 \mathrm{~g})$, fibre $(0.7 \mathrm{~g})$, sulphur (24 mg), chlorine (38 $\mathrm{mg})$ and calcium $(20 \mathrm{mg})$ on per $100 \mathrm{~g}$ fresh weight basis. India is the second largest tomato 
producing country in the world after China and contributes about $11.5 \%$ of the total global tomato production. Andhra Pradesh, Karnataka, Madhya Pradesh, Telengana and Odisha are the five major tomato growing states of the country. (Horticultural statistic at a glance, 2017) In tomato, anthesis and dehiscence occur between 7 to 8 am and 9 to 11 am respectively. Pollen fertility is maximum on the day of anthesis and stigma is fully receptive at 16 hours before anthesis to the day of anthesis (Sindhu et al., 1980).

Genetic variability is defined as the occurrence of a high degree of variation differences among individuals due to differences in their genetic composition and environment in which they are based (Falconer \& Mackey, 1996). The basic requirement for genetic improvement of a crop is to utilise the available or created genetic variability. Wild tomatoes have a large genetic diversity, especially within the selfincompatible species like, $L$. chilense and $L$. peruvianum (Rick 1998). The genetic variations present in the wild species have been investigated intensively for the specific trades and is being exploited in tomato breeding (Larry and Joanne, 2007). Utilisation of desirable genes conferring resistance to biotic and abiotic stresses available in different wild and cultivated gene pools could be possible through hybrid breeding programme. The basic force behind such a miracle achievement in relation to production and productivity of this crop was of development of F1 hybrids suitable for different agro-climatic conditions. The tomato hybrids got quick popularity due to occurrence of heterosis for fruit yield characteristics.

The agro-climatic conditions of coastal Odisha are known for variability, uncertainty and extremity. This region is 'hot spot' of almost all the biotic and abiotic stresses, like early and late onset of monsoon, flush rains, cyclone, erratic and unevenly distributed rainfall, bacterial wilt, fruit rot etc. With these collages cultivation of conventional varieties of tomato is prone to be uneconomical enterprise. Hybrids have been found to be more suitable for ensuring good yield even under such extreme agro ecological situations.

Tomato grown during the main season (winter) causes a glut of produce in the market and its sale price is also very low. But the crop grown in rainy season has a better demand and is much remunerative for the farmer.

With a view to combating these problems, evaluation of hybrids in rainy season in coastal plain zone of Odisha is indispensable for boosting the production and price of tomatoes in the state. Therefore, an experiment was planned to develop and evaluate the available hybrids of tomato during rainy season.

\section{Materials and Methods}

A set of $10 \times 10$ half diallel crosses of tomato excluding reciprocals (45 $\mathrm{F}_{1}$ hybrids) were evaluated along with their 10 parents (BT 2, BT 106, BT 317, BT 22-4-1, BT 306-1-2, BT 413-1-2, BT 429-1-1, BT 305-2-4-2, TOBW3 , BT 215-3-3-1) in a randomized block design with three replications at the experimental farm of All India Coordinated Research Project on Vegetable Crops, OUAT, Bhubaneswar. Seeds were sown in nursery bed on 20.06.2017 and seedlings were transplanted on 20.07.2017. Plant to plant spacing was $40 \mathrm{~cm}$ and row to row spacing was $50 \mathrm{~cm}$. Eighteen plants were accommodated in each plot having $1.8 \mathrm{~m} \mathrm{x}$ $2.4 \mathrm{~m}$ plot size. Recommended cultural practices were followed to raise a good crop. Observations were recorded on 5 randomly taken plants of parents and $\mathrm{F}_{1} \mathrm{~s}$ for the characters viz., plant height, days to $1^{\text {st }}$ flowering, number of clusters per plant, 
number of fruits per plant, fruit length, fruit girth, fruit pericarp thickness, number of locules per fruit, average fruit weight and fruit yield per plant. Statistical analysis was performed in accordance with the procedure mentioned by Pansey and Sukhatme (1967).

\section{Results and Discussion}

The mean performances of parents and $F_{1}$ hybrids for all quantitative and qualitative characters studied have been presented in Table 1. Like the parents, all the $45 \mathrm{~F}_{1}$ hybrids exhibited variation for the characters studied.

\section{Days to first flowering}

The mean values of the parents are presented in Table 1. It was observed that the days to first flowering ranged from 69.33 days in $\mathrm{BT}$ $317\left(\mathrm{P}_{3}\right)$ to 81.00 days in BT 413-1-2 $\left(\mathrm{P}_{6}\right)$. In case of hybrids, the mean values ranged from 64.00 days in (2x3) BT $106 \times$ BT 317 to 82.33 days in $(6 \times 9)$ BT 413-1-2 x TOBW-3 for days to first flowering. Lowest mean value that is earliness was observed in (2x3) BT 106 x BT 317 i.e. 64.00 days which is the best hybrid for this character.Variability in days to first flowering has also been reported by Ali et al., (2012), Shankar et al., (2013) and Said et al., (2014).

\section{Number of clusters per plant}

The number of clusters per plant is an important yield determining trait. Higher number of flowering clusters may lead to greater number of fruits per plant in favourable conditions. The genotype BT 317 $\left(\mathrm{P}_{3}\right)$ showed highest value for the character number of clusters/plant (28.23). Again, minimum value for the above mentioned character (14.00) was recorded in BT 413-1-2 $\left(\mathrm{P}_{6}\right)$. However, in hybrids the range was 16.13 in $(1 \times 6)$ BT $2 \times$ BT $413-1-2$ to 31.37 in $(4 \times$ 7) BT 22-4-1 x BT 429-1-1 for number of clusters/plant. The best hybrid showing highest mean value was $(4 \times 7)$ BT 317 X BT 215-3-3-1 (31.37) followed by (3X10) BT 317XBT 215-3-3-1 (30.90). The results of present investigation could also be compared with findings of Sekhar et al., (2009), Alam et al., (2010), and Singh et al., (2014).

\section{Number of fruits / plant}

The difference among the hybrids with respect to number of fruits per plant was highly significant which varied from 10.96 (BT 4131-2 $\left(\mathrm{P}_{6}\right)$ to $25.73 \mathrm{BT} 317\left(\mathrm{P}_{3}\right)$ for parents and 13.26 in $(4 \times 6)$ BT $22-4-1 \times$ BT $413-1-2$ to 27.18 in case of $(3 \times 10)$ BT $317 \times$ BT 215-33-1 for hybrids.

Maximum number of fruits per plant were observed in (3 x 10) BT 317 x BT 215-3-3-1 (27.18) followed by (4x7) BT 317 X BT 2153-3-1 (26.12) which were significantly higher than that in all the other hybrids tested in present investigation. The results of present study were in accordance with those reported by Sekhar et al., (2009), Saleem et al., (2013) and Singh et al., (2014).

\section{Plant height}

Plant height ranged from $106.53 \mathrm{~cm}$ in BT 317 $\left(\mathrm{P}_{3}\right)$ to $71.80 \mathrm{~cm}$ in $\mathrm{BT}$ 413-1-2 $\left(\mathrm{P}_{6}\right)$. For hybrids the range was $75.93 \mathrm{~cm}$ in 1 x 6 (BT 2 $\mathrm{x}$ BT $413-1-2)$ to $112.81 \mathrm{~cm}$ in (1 x 10), BT 2 $\mathrm{x}$ BT 215-3-3-1 for plant height and cross $(3 \times 7)$ BT 317 X BT429-1-1 (110.40 cm) showed significantly highest value for this character. Variability in plant at flowering and fruiting has also been obtained by Ali et al., (2012), Shankar et al., (2013), Singh et al., (2013), Saleem et al., (2013).

\section{Fruit length (cm)}

Significant difference for fruit length was noted among the hybrids evaluated. 
Table.1 Mean performance of parents and hybrids in kharif tomato

\begin{tabular}{|c|c|c|c|c|c|c|c|c|c|c|c|}
\hline $\begin{array}{l}\text { Sl. } \\
\text { No. }\end{array}$ & $\begin{array}{l}\text { Parents/ } F_{1} \\
\text { Hybrids }\end{array}$ & $\begin{array}{l}\text { Days to } \\
\text { first } \\
\text { flowering } \\
\text { (Days after } \\
\text { sowing) }\end{array}$ & $\begin{array}{l}\text { No. of } \\
\text { clusters/plant }\end{array}$ & $\begin{array}{l}\text { No of } \\
\text { fruits/plant }\end{array}$ & $\begin{array}{l}\text { Plant } \\
\text { height } \\
\text { (cm) }\end{array}$ & $\begin{array}{l}\text { Fruit } \\
\text { length } \\
(\mathrm{cm})\end{array}$ & $\begin{array}{l}\text { Fruit } \\
\text { girth } \\
(\mathrm{cm})\end{array}$ & $\begin{array}{l}\text { Fruit } \\
\text { pericarp } \\
\text { thickness } \\
\text { (cm) }\end{array}$ & $\begin{array}{l}\text { No of } \\
\text { locules/fruit }\end{array}$ & $\begin{array}{l}\text { Average } \\
\text { fruit } \\
\text { wt.(g) }\end{array}$ & $\begin{array}{l}\text { Fruit yield } \\
\text { /plant }\end{array}$ \\
\hline 1 & BT 2 (P1) & 77.00 & 17.87 & 15.93 & 77.09 & 3.51 & 2.96 & 0.38 & 3.43 & 22.55 & 296.15 \\
\hline 2 & BT106 (P2) & 72.00 & 24.27 & 20.49 & 87.10 & 3.53 & 3.03 & 0.43 & 2.37 & 24.57 & 336.90 \\
\hline 3 & BT 317 (P3) & 69.33 & 28.23 & 25.73 & 106.53 & 4.88 & 4.06 & 0.60 & 2.17 & 30.50 & 718.78 \\
\hline 4 & BT 22-4-1(P4) & 74.00 & 25.93 & 23.30 & 86.44 & 3.59 & 3.13 & 0.45 & 2.63 & 22.57 & 382.41 \\
\hline 5 & BT 306-1-2 (P5) & 76.00 & 24.03 & 17.67 & 101.01 & 3.91 & 3.36 & 0.36 & 3.87 & 25.00 & 249.54 \\
\hline 6 & BT 413-1-2 (P6) & 81.00 & 14.00 & 10.96 & 71.80 & 3.12 & 2.65 & 0.36 & 3.53 & 19.17 & 116.84 \\
\hline 7 & BT429-1-1 (P7) & 75.67 & 25.07 & 21.03 & 96.05 & 3.24 & 3.00 & 0.36 & 2.63 & 23.93 & 307.74 \\
\hline 8 & $\begin{array}{l}\text { BT 305-2-4-2 } \\
\text { (P8) }\end{array}$ & 73.67 & 25.37 & 20.78 & 98.08 & 4.00 & 3.84 & 0.49 & 3.47 & 26.10 & 329.52 \\
\hline 9 & TOBW -3 (P9) & 80.67 & 23.50 & 19.05 & 86.84 & 4.53 & 4.00 & 0.58 & 2.67 & 29.00 & 426.55 \\
\hline 10 & $\begin{array}{l}\text { BT 215-3-3-1 } \\
\text { (P10) }\end{array}$ & 73.33 & 21.40 & 18.88 & 100.98 & 4.90 & 3.52 & 0.54 & 2.62 & 28.77 & 370.61 \\
\hline \multicolumn{12}{|l|}{ F1 } \\
\hline 1 & P1 XP 2 & 69.67 & 26.53 & 18.17 & 91.20 & 4.45 & 3.36 & 0.42 & 2.83 & 32.27 & 437.79 \\
\hline 2 & P1 XP 3 & 67.67 & 26.57 & 19.63 & 107.30 & 4.16 & 3.72 & 0.53 & 2.07 & 32.30 & 405.40 \\
\hline 3 & P1 X P4 & 71.33 & 24.93 & 21.24 & 89.30 & 3.25 & 3.19 & 0.43 & 2.73 & 24.17 & 372.13 \\
\hline 4 & P1 XP 5 & 65.33 & 25.77 & 15.95 & 103.87 & 4.41 & 3.54 & 0.43 & 2.30 & 19.27 & 355.52 \\
\hline 5 & P1 XP 6 & 74.67 & 16.13 & 13.54 & 75.93 & 4.17 & 4.05 & 0.47 & 3.09 & 21.10 & 210.29 \\
\hline 6 & P1 X P7 & 68.67 & 20.00 & 17.37 & 101.30 & 3.37 & 3.09 & 0.40 & 2.53 & 28.77 & 323.07 \\
\hline 7 & P1 X P8 & 65.00 & 27.80 & 18.27 & 107.43 & 3.08 & 3.42 & 0.47 & 2.87 & 29.40 & 388.07 \\
\hline 8 & P1 X P9 & 70.33 & 24.44 & 21.67 & 90.20 & 3.92 & 3.61 & 0.53 & 2.63 & 18.40 & 380.55 \\
\hline 9 & P1X P10 & 70.33 & 22.33 & 19.06 & 112.81 & 4.10 & 3.26 & 0.58 & 2.60 & 25.30 & 376.87 \\
\hline 10 & P2 X P3 & 64.00 & 27.83 & 22.33 & 97.80 & 5.52 & 4.20 & 0.56 & 2.30 & 23.77 & 431.37 \\
\hline 11 & P2 X P4 & 69.67 & 28.07 & 21.55 & 89.38 & 3.51 & 3.03 & 0.47 & 2.70 & 27.03 & 409.81 \\
\hline 12 & P2 X P5 & 71.67 & 19.30 & 14.87 & 102.91 & 3.83 & 3.48 & 0.45 & 2.17 & 28.03 & 365.30 \\
\hline 13 & P2 X P6 & 70.67 & 19.30 & 13.55 & 91.48 & 4.09 & 3.84 & 0.34 & 2.30 & 21.93 & 308.73 \\
\hline 14 & P2 XP 7 & 71.00 & 22.30 & 19.92 & 99.95 & 4.00 & 3.76 & 0.45 & 2.20 & 26.50 & 413.03 \\
\hline
\end{tabular}




\begin{tabular}{|c|c|c|c|c|c|c|c|c|c|c|c|}
\hline 15 & P2 X P8 & 74.67 & 28.00 & 21.55 & 97.38 & 4.06 & 3.83 & 0.27 & 2.73 & 24.13 & 385.26 \\
\hline 16 & P2 X P9 & 75.67 & 27.27 & 21.02 & 90.10 & 5.51 & 4.35 & 0.35 & 2.27 & 33.33 & 536.95 \\
\hline 17 & P2X P10 & 76.00 & 23.33 & 16.99 & 95.61 & 5.04 & 3.95 & 0.52 & 2.73 & 32.30 & 437.47 \\
\hline 18 & P3 X P4 & 67.67 & 24.60 & 19.44 & 107.72 & 3.64 & 3.30 & 0.52 & 2.20 & 29.80 & 383.40 \\
\hline 19 & P3 X P5 & 69.00 & 27.33 & 21.55 & 108.34 & 3.51 & 3.19 & 0.47 & 2.27 & 26.70 & 363.50 \\
\hline 20 & P3 X P6 & 68.33 & 22.03 & 16.39 & 100.48 & 3.49 & 4.05 & 0.48 & 2.70 & 21.73 & 229.58 \\
\hline 21 & P3 X P7 & 73.00 & 25.43 & 21.85 & 110.40 & 3.85 & 3.31 & 0.42 & 2.50 & 25.43 & 404.49 \\
\hline 22 & P3 X P8 & 71.00 & 27.17 & 22.60 & 108.06 & 3.41 & 4.02 & 0.53 & 2.77 & 30.17 & 419.66 \\
\hline 23 & P3 X P9 & 77.33 & 26.03 & 23.37 & 101.00 & 5.46 & 4.23 & 0.57 & 2.15 & 23.93 & 431.15 \\
\hline 24 & P3 X P10 & 73.00 & 30.90 & 27.18 & 106.47 & 5.96 & 5.86 & 0.60 & 2.40 & 37.00 & 943.64 \\
\hline 25 & P4 X P5 & 69.00 & 25.53 & 22.75 & 87.63 & 4.93 & 5.01 & 0.43 & 2.15 & 26.16 & 518.67 \\
\hline 26 & P4 X P6 & 77.67 & 20.53 & 13.26 & 70.19 & 4.30 & 3.51 & 0.58 & 3.59 & 21.68 & 289.22 \\
\hline 27 & P4 X P7 & 72.00 & 31.37 & 26.13 & 106.83 & 4.98 & 4.64 & 0.53 & 2.47 & 28.00 & 610.87 \\
\hline 28 & P4X P8 & 71.67 & 26.40 & 22.77 & 97.52 & 4.26 & 5.17 & 0.55 & 2.67 & 22.80 & 450.89 \\
\hline 29 & P4 X P9 & 77.00 & 24.73 & 22.30 & 88.23 & 4.29 & 3.58 & 0.51 & 2.64 & 24.89 & 395.57 \\
\hline 30 & P4 X P10 & 77.00 & 24.33 & 22.68 & 95.73 & 3.90 & 2.88 & 0.47 & 2.38 & 26.43 & 391.74 \\
\hline 31 & P5 X P6 & 70.67 & 22.33 & 13.36 & 99.27 & 3.58 & 2.72 & 0.33 & 2.87 & 22.14 & 236.24 \\
\hline 32 & P5 X P7 & 72.00 & 23.47 & 15.42 & 97.42 & 4.61 & 2.89 & 0.41 & 2.73 & 24.23 & 361.12 \\
\hline 33 & P5 X P8 & 71.67 & 28.20 & 22.47 & 102.42 & 3.57 & 3.23 & 0.45 & 3.33 & 26.50 & 413.59 \\
\hline 34 & P5 X P9 & 80.00 & 27.27 & 19.08 & 107.42 & 4.56 & 3.94 & 0.44 & 4.20 & 31.20 & 399.54 \\
\hline 35 & P5 X P10 & 74.33 & 22.07 & 19.97 & 104.59 & 4.62 & 3.97 & 0.52 & 2.87 & 32.17 & 405.13 \\
\hline 36 & P6 X P7 & 74.33 & 23.17 & 14.13 & 88.19 & 4.29 & 2.91 & 0.34 & 2.63 & 23.47 & 303.83 \\
\hline 37 & P6 X P8 & 74.33 & 20.10 & 16.75 & 79.67 & 4.44 & 2.79 & 0.43 & 2.87 & 25.00 & 390.39 \\
\hline 38 & P6 X P9 & 82.33 & 19.53 & 16.75 & 83.64 & 4.16 & 3.73 & 0.56 & 5.09 & 23.93 & 391.86 \\
\hline 39 & P6 X P10 & 75.33 & 23.60 & 20.71 & 79.13 & 4.23 & 3.28 & 0.51 & 3.07 & 22.68 & 397.65 \\
\hline 40 & P7 X P8 & 68.00 & 23.13 & 19.25 & 98.62 & 4.68 & 2.84 & 0.52 & 2.37 & 23.80 & 407.24 \\
\hline 41 & P7 X P9 & 79.33 & 22.97 & 22.48 & 96.91 & 5.41 & 3.63 & 0.46 & 3.73 & 30.02 & 497.71 \\
\hline 42 & P7 X P10 & 71.00 & 25.63 & 21.77 & 102.05 & 4.57 & 3.59 & 0.45 & 2.76 & 26.07 & 447.41 \\
\hline 43 & P8 X P9 & 75.00 & 28.63 & 23.30 & 99.10 & 4.58 & 3.03 & 0.45 & 2.83 & 27.87 & 416.96 \\
\hline 44 & P8 X P10 & 70.67 & 23.60 & 23.45 & 97.87 & 4.89 & 4.60 & 0.64 & 3.03 & 33.00 & 483.02 \\
\hline \multirow{5}{*}{45} & P9 X P10 & 75.67 & 28.10 & 22.67 & 101.23 & 6.10 & 5.70 & 0.61 & 2.90 & 35.20 & 651.24 \\
\hline & SE & 1.6224 & 1.0391 & 0.8902 & 1.8974 & 0.1158 & 0.1152 & 0.0236 & 18.7180 & 0.7303 & 17.3746 \\
\hline & $\mathrm{SE}(\mathrm{d})$ & 2.2944 & 1.4695 & 1.2590 & 2.6833 & 0.1676 & 0.1629 & 0.0333 & 26.4712 & 1.0328 & 24.5714 \\
\hline & CD 5\% & 4.4970 & 2.8801 & 2.4676 & 5.2592 & 0.3285 & 0.3193 & 0.0653 & 51.8836 & 2.0242 & 48.1599 \\
\hline & CD $1 \%$ & 5.9195 & 3.7912 & 3.2482 & 6.9228 & 0.4324 & 0.4202 & 0.0860 & 0.7823 & 2.6645 & 63.3941 \\
\hline
\end{tabular}


The mean value for the fruit length in different parents and hybrids exhibited a range of $3.12 \mathrm{~cm} \mathrm{BT} \mathrm{413-1-2}\left(\mathrm{P}_{6}\right)$ to $4.90 \mathrm{~cm}$. BT 215-3-3-1 $\left(\mathrm{P}_{10}\right)$ and $3.08 \mathrm{~cm}$ in $(1 \times 8)$ BT $2 \mathrm{x}$ BT $305-2-4-2$ to $6.10 \mathrm{~cm}$ in $(9 \mathrm{x} 10)$ TOBW-3 x BT 215-3-3-1 respectively. Significantly highest value for this trait was observed in cross (9x10) TOBW-3 X BT 215$3-3-1(6.10 \mathrm{~cm})$ which was followed by $(3 \mathrm{x}$ 10) BT 317 x BT 215-3-3-1 (5.96). Variability in fruit length of tomato hybrids has also been reported by Ali et al., (2012), Saleem et al., (2013), Shankar et al., (2013) and Said et al., (2014).

\section{Fruit girth (cm)}

Fruit girth ranged from $2.65 \mathrm{~cm}$ in BT 413-1$2\left(\mathrm{P}_{6}\right), 4.06 \mathrm{~cm}$ in $\mathrm{BT} 317\left(\mathrm{P}_{3}\right)$ for parents. In case of hybrids the range of Fruit girth varied from $2.72 \mathrm{~cm}$ in $(5 \times 6)$ BT 306-1-2 x BT $413-1-2$ to $5.86 \mathrm{~cm}$ in $(3 \times 10)$ BT $217 \times$ BT 215-3-3-1. Significantly highest value for this trait was observed in cross $(3 \times 10)$ BT $217 \mathrm{x}$ BT $215-3-3-1(5.86 \mathrm{~cm})$ followed by $(9 \times 10)$ TOBW-3 X BT 215-3-3-1(5.70cm). There were significant variations in fruit girth across the parents and hybrids. The findings are in accordance with Ali et al., (2012) and Shankar et al., (2013).

\section{Fruit pericarp thickness $(\mathrm{cm})$}

The perusal of results on pericarp thickness indicated significant variations among the parents and hybrids for this character. Mean value for parents ranges from $0.31 \mathrm{~cm}$ in $\mathrm{BT}$ 4.3-1-2 $\left(\mathrm{P}_{6}\right)$ to $0.60 \mathrm{~cm}$ in BT $317\left(\mathrm{P}_{3}\right)$ and for hybrids $0.27 \mathrm{~cm}$ in $(2 \times 8)$ BT $106 \times$ BT $305-$ $2-4-2$ to $0.64 \mathrm{~cm}$ in $(8 \times 10)$ BT $305-2-4-2 \times$ BT 215-3-3-1. Significantly highest value for this trait was observed in cross $(8 \times 10) \mathrm{BT}$ 305-2-4-2 x BT 215-3-3-1 $(0.64 \mathrm{~cm})$ followed by (9x10) TOBW-3 X BT 215-3-3-1(0.61cm). Almost similar findings on variability in fruit pericarp thickness of tomato hybrids have also been observed by Sekhar et al., (2009), Shankar et al., (2013) and Singh et al., (2014).

\section{Number of locules / fruit}

The analysed data on number of locules per fruit indicated that there were significant differences among the parents and hybrids. The mean for parents and hybrids ranged from 2.17 in $\mathrm{P}_{3}$ (BT 317) to 3.87 in BT 306-1$2\left(\mathrm{P}_{5}\right)$ and 2.07 in $(1 \times 3)$ BT $2 \times$ BT 317 to 5.09 in $(6 \times 9)$ BT $413-1-2 \times$ TOBW-3 respectively. Similar results on variability in number of locules / fruit has been obtained by Kurian et al., (2001), Sekhar et al., (2009) and Shankar et al., (2013).

\section{Average fruit weight}

There was a highly significant difference among 10 parents and 45 hybrids with respect to average fruit weight. The fruit weight ranged between $19.17 \mathrm{gm}$ in $\mathrm{BT} 413-1-2\left(\mathrm{P}_{6}\right)$ and $30.50 \mathrm{~g}$ in BT $317\left(\mathrm{P}_{3)}\right.$ for parents and $18.40 \mathrm{~g}$ in $(1 \times 9) \mathrm{BT} 2 \mathrm{x}$ TOBW -3 to $37.00 \mathrm{~g}$ in $(3 \times 10)$ BT $317 \times$ BT 215 -3-3-1for hybrids. Significantly highest value for this trait was observed in cross $(3 \times 10)$ BT $217 \mathrm{x}$ BT 215-3-3-1 (37.00 g) followed by (9x10) TOBW-3 X BT 215-3-3-1(35.20 g) Corresponding to the above results variability in average fruit weight and inverse association with number of fruit per plant have also been reported by Sekhar et al., (2009), Singh et al., (2013), Cheema et al., (2013) and Said et al., (2014).

\section{Fruit yield per plant}

The fruit yield is supposed to be ultimate economic trait in tomato as well as other fruit vegetables. Fruit yield per plant is accurate assessment of potentiality of a particular hybrid at individual plant level. The data on fruit yield per plant exhibited a wide 
variability among the hybrids evaluated. The highest $(718.78 \mathrm{~g})$ fruit yield per plant was recorded in BT $317\left(\mathrm{P}_{3}\right)$ followed by TOBW$3(426.55 \mathrm{~g})\left(\mathrm{P}_{9}\right)$, lowest yield of $116.84 \mathrm{~g}$ was recorded in BT 413-1-2 $\left(\mathrm{P}_{6}\right)$. However, in case of hybrids fruit yield per plant was ranged from $219.29 \mathrm{~g}$ in $(1 \times 6)$ BT $2 \times$ BT 413-1-2 to $943.64 \mathrm{~g} /$ plant in (3 x 10) BT 317 $x$ BT 215-3-3-1. Significantly highest value for this trait was observed in cross $(3 \times 10)$ BT 217 x BT 215-3-3-1 (943.64 g) followed by $(9 x 10)$ TOBW-3 X BT 215-3-3-1(651.24 g) and $(4 \times 7)$ BT 22-4-1 X BT 429-1-1 (610.87).Variability in fruit yield per plant in tomato hybrids have also been reported by Sharma et al., (2013), Saleem et al., (2013) and Shankar et al., (2013).

\section{Acknowledgement}

The authors acknowledge with thanks the facilities and funds provided by the All India Coordinated Research Project on Vegetable Crops(ICAR), Orissa University of Agriculture and Technology, Bhubaneswar, Odisha, India as well as University Grants Commission.

\section{References}

Alam, M.S., Sultana, N., Ahmed, S., Hossain, M.M. and Islam, A.K.M.A. 2010. Performance of heat tolerant tomato hybrid lines under hot, humid condition. Bangladesh J. Agril.Res., 35(3): 367373.

Ali, W., Jilani, M.S., Naeem, N., Waseem, K., Khan, J., Ahmad, M.J. and Arullah, G. 2012. Evaluation of different hybrids of tomato under the climatic conditions of Peshawar, Sarhad J. Agric., 28(2): 200211.

Cheema, D.S., Singh, N. and Jindal, S.K. 2013. Evaluation of indeterminate tomato hybrids for fruit yield and quality traits under net house and open field condition, Veg. sci., 40(1): 45-49.

Falconer, D.S., Mackay, T. F. C. Introduction to Quantitative Genetics. 4th ed. London, UK: Benjamin Cummings. 1996, 122-125.

Horticultural statistic at a glance, 2017. Horticulture Statistics Division. Department of Agriculture, Cooperation \& Farmers Welfare, Ministry of Agriculture \& Farmers Welfare Government of India.

Kurain, A., Peter, K.V. and Rajan, S. 2001. Heterosis for yield components and fruit characters in tomato. J. Tropical Agric., 39: $5-8$.

Larry, R., and Joanne, L. 2007. Genetic improvement of solanaceous crop. EnfieldSci. pub., 2p.

Panse V.G. and Sukhatme, P.V. 1967. Statistical methods for Agriculture workers. Indian council of Agriculture, New Delhi.

Rick, C.M., 1998. Tomato-like nightshades, affinities and auto-ecology and breeder opportunities. Economic Botany, 42: 145-154.

Said, F.A., Farsi, K.A., Khan, I.A., Ali, A., Khan, M.M. and Iqbal, Q. 2014. Evaluation of adaptability and nutritional quality of 54 tomato accession grown in Oman. J. Food Agric. \& Environ, 12(2): 40-50.

Saleem, M.Y., Iqbal, Q. and Asghar, M. 2013. Genetic variability, heritability character association and path analysis in F1hybrids of tomato. Pak. J. Agri. Sci., 50(4): 649-653.

Sekhar, L., Prakesh, B.G., Salimath, P.M., Sridevi, O. and Patil, A.A. 2009. Performance of productive single cross hybrids in tomato (Solanum lycopersicon L.). Karnataka J. Agric. Sci., 22(4): 877-878.

Shankar, A., Reddy, R.V.S.K., Sujata, M. and Pratap, M. 2013. Genetic variability studies in F1 generation of tomato 
(Solanum lycopersicon L.) JOSR J. Agric. Vet. Sci. 4(5): 31-34.

Sharma, D., and Sharma, H.R. 2013. Production and evaluation of tomato hybrids using diallele genetic design. Indian J. Hort., 70: 4-6.

Sindhu, A.S., Kalloo, and Pandita, M. 1980. Studies on some important aspects of floral biology in vegetable crops.
Haryana J. Hort. Sci., 9: 20-21.

Singh, T., Singh, N., Bahuguna, A., Nautiyal, M. and Sharma, V.K. 2014. Performance of tomato (Solanum lycopersicon L.) hybrids for growth, yield and quality inside polyhouse under Mid Hill Condition of Uttarakhand, Am. J. Drug Discov. Dev., 68: $1-8$.

\section{How to cite this article:}

Rojalin Pradhan, Alok Nandi, G.S. Sahu and Tripathy, P. 2019. Evaluation of Tomato (Solanum lycopersicum L.) Hybrids during Rainy Season in Coastal Plain of Odisha, India. Int.J.Curr.Microbiol.App.Sci. 8(07): 2410-2417. doi: https://doi.org/10.20546/ijcmas.2019.807.296 